\title{
KiHS: Bridging the Traditional and Virtual Classroom in Canada's First Nation Schools
}

\author{
Brian Walmark \\ Keewaytinook Okimakanak $<$ brianwalmark@knet.ca $>$
}

\begin{abstract}
KO's Internet High School (KIHS) provides Grade Nine and Ten students from remote and isolated First Nation schools in Ontario's far north with the opportunity to receive a high quality secondary school education without having to leave their families and communities. Until KiHS, students as young as fourteen had to leave home and attend school in urban communities. With KiHS, these students can remain home during these critical years and are better equipped both academically and socially to cope with the challenges of city life when they choose to complete their high school education in the south.
\end{abstract}

\section{Introduction}

In 2002, Indian and Northern Affairs, a department of the Canadian Government, released a long awaited final report by the National Working Group on Education. Aboriginal educators, hand selected by the Minister of Indian Affairs, were mandated by the federal government to examine the challenges that prevent many First Nation students from succeeding in elementary school, high school and beyond. While there was little new in the report, the Working Group brought national attention to the crisis of First Nation education in Canada. What the final report did not highlight were some of the innovative ways in which ICTs have been used to improve the quality of education on some of Canada's First Nations communities. One such application is KiHS, the Internet High school created by Keewaytinook Okimakanak in Ontario's far north.

In 1999, Keewaytinook Internet High School (KiHS) was established by Keewaytinook Okimakanak (KO), one of the seven tribal councils in Nishnawbe Aski. KO chiefs mandated the creation of a pilot project to determine whether the Internet could be an effective tool to deliver education. The purpose of the project, as directed by the $\mathrm{KO}$ chiefs, was to find a method for grade nine and ten students to remain at home in their community while earning accredited high school courses. In the past, students had to leave their families to continue their secondary school education at an urban centre in the south such as Sioux Lookout or Thunder Bay. Many of these students were as young as fourteen years of age when they had to leave home for the first time. Following a successful evaluation, the first intake of thirty grade 9 students was admitted to KiHS from three KO communities. By 2001, KiHS expanded to eight communities and had an enrolment of 79 students. Expansion continued the following year with the addition of five new First Nation communities with a total of 134 students. In $2003 \mathrm{KiHS}$ began its fourth year of operation with 142 students in 13 communities. Currently, there are KiHS classrooms in the following First Nation communities: Cat Lake, Deer Lake, Eabametoong, Fort Severn, Fort William, Bearskin Lake, Keewaywin, Kejick Bay, North Spirit Lake, Poplar Hill, Sachigo, Webequie and Weagamow.

KiHS is not a distance education program. It represents a unique departure from both traditional classroom models and conventional models of distance education. Unlike other Internet based secondary 
school programs, KiHS requires students to attend a classroom in their community from 9:00 a.m. to 4:00 p.m. under the direction of an accredited teacher who is responsible for classroom management, tutoring, and mentoring as the students complete their assignments online. In addition to the normal classroom responsibilities, each KiHS teacher is a specialist responsible for delivering two courses to classes across the network. The KiHS teacher for example in Eabmatoong First Nation is a specialist in computer science and, while he is responsible for classroom management in his home community, he teaches computer science to all 148 students attending the 13 KiHS classrooms across Ontario's far north.

KiHS does not use Blackboard or any other Learning Management System. Rather, KiHS has developed its own platform that has been created to suit the needs of Aboriginal students and teachers. The KiHS platform has been adapted for use by other Aboriginal educational organizations including OshkiPimache-O-Win, Nishnawbe Aski's post-secondary institute. The Faculty of Education at Lakehead University in Thunder Bay, Canada is considering using the platform for delivery of its proposed community-based Bachelor of Education degree.

KiHS is currently seeking funding to conduct a comprehensive evaluation of the program. There are no plans to expand KiHS to include the final two years of high school. Some of the political leadership and many parents have indicated that they would like KiHS to include the final two years of high school while others argue that the youth should complete their education in the larger well-equipped institutions in the south. Discussion involving future growth focuses on expanding KiHS to Grade 7 and 8 classrooms where the grade gap between First Nations and mainstream elementary students begins to widen.

Like most First Nations controlled educational organizations in Canada, the greatest challenge to KiHS is achieving sustainable funding from the federal Department of Indian Affairs. Currently in Ontario, the Department provides the same per capita funding for elementary school students and secondary school students attending First Nations schools. There is no additional funding available for ICTs other than what is found in the per capita grant, nor is there any additional funds available to conduct a comprehensive independent evaluation to assess the quality of education KiHS students receive during their terms in Grades Nine and Ten.

KiHS provides students from remote and isolated First Nation schools in Ontario's far north with the opportunity to receive a high quality secondary school education without having to leave their families and communities. Until the establishment of KiHS, students as young as fourteen, if they wanted to graduate with a high school diploma, had to leave home and attend school in urban communities. With KiHS, these students can remain home during these critical years and are better equipped both academically and socially to cope with the challenges of city life when they choose to complete their high school education in the south. For more information, see www.kihs.knet.ca. 